\title{
Students Satisfaction of the Industrial Skills Enhancement Program (INSEP)
}

\author{
Christina Andin, Abdul Said Ambotang \\ Faculty of Psychology and Education, Universiti Malaysia Sabah, Kota Kinabalu, Sabah, East Malaysia \\ Email address: \\ christina@ums.edu.my (C.Andin), said@ums.edu.my (A. S. Ambotang)
}

To cite this article:

Christina Andin, Abdul Said Ambotang. Students Satisfaction of the Industrial Skills Enhancement Program (INSEP). International Journal of Vocational Education and Training Research. Vol. 1, No. 2, 2015, pp. 27-33. doi: 10.11648/j.ijvetr.20150102.13

\begin{abstract}
Policy makers in higher-education institutes have recently paid closer attention to graduate enrichment programs such as INSEP. The program aimed to prepare unemployed graduates with 'ready to work' knowledge and skills. The objectives of this study are to examine the satisfaction of the former students of the INSEP program in regards to three aspects, including inputs, implementation and learning impacts of the program. This study adopts the quantitative approach, using a set of questionnaires as an instrument. The sample size used for the study includes 71 respondents out of 82 graduates. This study was conducted one year after the students completed the INSEP program. The findings in regards to the program's inputs showed that the students were satisfied with the content of the program, but were less satisfied with the quality of the teaching staff and infrastructure. The students were also less satisfied with the implementation of the program, especially the implementation of industrial training. In regards to learning impacts, the students were more satisfied with the program's impacts on soft skills, compared to technological knowledge and skills. This study sheds light on several aspects of the program that need further improvement.
\end{abstract}

Keywords: Graduate, Training, Satisfaction

\section{Introduction}

For the past few years, the Malaysian government has come up with many training programs in its effort to assist university graduates in gaining industry-specific skills. One of the programs is the Industrial Skills Enhancement Program (INSEP). The training program intends to provide unemployed graduates with specific skills, making them more marketable to particular industries in the employment market. According to the Graduate Tracer Study report in 2008, a total of approximately 150,000 students graduated every year in Malaysia. The percentage of graduates employed after graduation was about 50.5 percent, while 21.7 percent of graduates were unemployed, and the remaining graduates decided to continue their studies [1]. One of the reasons for this unemployment is related to a mismatch between what is needed by industry, and what is offered by graduates [2] Therefore, INSEP was formulated in order to assist graduates facing challenges of structural unemployment, and to equip them with the transferable skills and competencies needed in order to acquire 'carry forward' or work-ready skill sets applicable to workplace settings.

INSEP is a post-graduate program fully funded by
Perbadanan Tabung Pembangunan Kemahiran (PTPK), under the Economic Transformation Programme (ETP). In 2006 the program spent approximately 32 million [3]. Given the huge expenses involved in implementing the program, this study was carried out in order to investigate the effectiveness of the program in equipping Malaysia's workforce with the right competencies in technical disciplines and innovative capabilities, and in moving key trends and future technologies into marketplace significance. This is important for solving the problem of unemployment among graduates.

The objectives of the study are to investigate the satisfaction of former INSEP students in regards to the following aspects: (a) Inputs of the program: Content of the program, teaching staff and infrastructure; (b) Implementation: Teaching and learning activities, and industrial training; (c) Learning impacts of the program: Impacts on knowledge, technical skills, and soft skills.

\section{Review of Related Literature}

\subsection{Unemployment of Graduates}

There are many reasons why graduates are unemployed in Malaysia. One of the common reasons is the mismatch 
between the qualities that are required by employers, and the qualities offered by graduates [4]. This can be connected to the problem of a lack of employability skills among graduates, which are below average when compared to employer's expectations. From the employer's perspective, they need 'work-ready' graduates, with the skills, know-how, knowledge, attitude, behaviors and profit-making understanding that enables them to be effective workers [5]. They need workers with significant employability skills, that make them capable of securing employment, and enable them to contribute to achieving organizational goals [6], [7]. This is consistent with $21^{\text {st }}$ century skills requirements, where employers expect workers to have important skills, including work ethic, oral and written communications, teamwork and collaboration, and critical thinking and problem solving [8].

On the other hand, graduates are reportedly lacking in some basic skills, and also in a large number of applied skills such as oral and written communications, critical thinking and problem solving, professionalism and work ethic, teamwork and collaboration, working in diverse teams, applying technology, and leadership and project management [8]. In Malaysia, research has revealed that graduates are weak in regards to their command of English, and in their communication skills with the language. It also indicates that graduates have difficulty communicating and building interpersonal relationships, are passive and have no initiative, and are less independent in finishing their tasks. They also have attitude problems, are too choosy in jobs, lack team-working skills, show no initiative to learn, are selfish, and demand high salaries [9],[10].

\subsection{Training Program for Unemployed Graduates}

The issue of graduate unemployment demands the use of enrichment programs, such as INSEP. INSEP is a complimentary skills enhancement program aimed at increasing employability among fresh Malaysian graduates. Its main goal is to equip fresh graduates with appropriate skills and competencies, as well as innovative capabilities, in order to meet the demands of current and future challenges in the industry. The training programs have been developed based on the skills required by industries. The involvement of industries is required for the development of the training curriculum and structure, so that the program will be able to satisfy the needs of employers [11].

INSEP creates a win-win situation between industries and graduates. Industries will obtain employees who are equipped with work-ready skills. Graduates will benefit from the opportunity to be equipped with industry-relevant competencies. This will increase their potential to obtain more employment opportunities. They can also get free training, because the fee is fully funded by the government.

Basically the program involves two components. The first is based on campus teaching and learning activities, focusing on theoretical and practical learning through lectures, tutorials, group work, seminars and projects. The second component is an industrial placement, where students will be attached to industries. Through this placement, students will be exposed to real working environments where they can learn directly about the competencies required by industries.

\subsection{The Effectiveness of Training Programs: Evaluation Models}

There are many different types of evaluative measures, depending on the purpose of the evaluation [12]. This study aims to identify learner satisfaction within the INSEP program. In this respect, this study employed a combination of the Kirkpatrick evaluation model [13] and the CIPP model [14]. The Kirkpatrick model has been the one most widely recognized and used for evaluating training programs [15]. This model claims that training program effectiveness can be evaluated by examining it at four separate levels. These levels include reaction (how the training participant reacts to the program), learning (the extent to which participants increase their knowledge and skills), behavior (the extent to which behavior change occurs), and results (the final impact of the program). This study utilized the first two levels, namely the reaction level and the learning level. The evaluated components were categorized by following the components in the CIPP evaluation model.

The reaction level

The reaction level has been defined as how favorably learners react to training, as a measure of participant satisfaction with the training program $[13,16]$. This level can be a collection of reactions to the instructor and to the course, to the content and quality of training material, and to the learning environment. All these elements are very important for a high quality INSEP program. In order to reduce unemployment among graduates, the training program for unemployed graduates should provide sufficient learning experiences that prepare the graduates for being 'ready to work' in their chosen fields. These require special attention given to course content, teaching staff or instructors, related infrastructure, and teaching and learning activities.

The content of the courses offered in the program should be relevant to the needs of employers. The program should emphasize both the technical skills and soft skills in the job area. This is important, because the work world in the Knowledge Age requires a new mix of skills. Jobs that require routine manual and thinking skills are giving way to jobs that require higher levels of knowledge and applied skills, like expert thinking and complex communicating [17].

Infrastructure is one of the most important components that support the implementation of training programs. Adequate and appropriate facilities for supporting training include the following five elements, as are applied in best practices [18]: (a) Sufficient space for all attendees to sit comfortably during instruction, (b) sufficient room set-up for participants to interact with one another, (c) enough equipment for all attendees, and demonstration equipment for instructors/facilitators, (d) Space and facilities for small group exercises or hands-on training, using equipment as part of activity-based learning, and (e) Equipment, technical support, and resources sufficient for supporting training via technology, such as during instructor presentations or web-based training 
used by students to enhance learning.

Instructional design involves teaching and learning activities. One of the most important aspects that ensures the effective implementation of teaching and learning, is that instructors and classroom facilitators should be deemed competent in the focus area [19]. Teaching and learning activities should focus on student-directed learning, rather than teacher-centered learning. Within the traditional approach of teacher-centered learning, educators commonly provide so much information that students can comply with the learning objectives only by failing to think for themselves [20]. The transmission models of education compel teachers to instruct students in what to do, when to do it, and even how to behave while they do it. A narrow emphasis on memorizing facts and correctness can result in a pedagogy of 'intellectual hide-and-seek', in which teachers hold all the correct answers and students aim to seek out, memorize and parrot back those answers [21]. Such practices not only underestimate the importance of mind-building, but also deaden the personal value of the information being taught to students. Conversely, the active participation of students, for instance through participatory training methods, encourages teamwork and group problem solving. Training materials, including handouts, power-point presentations and flip charts, should be provided as visual aids that facilitate and enhance student's learning experiences.

The elements measured in this reaction level represent the input and process components of the CIPP evaluation model. The input evaluation of the CIPP model is conducted as a mean of establishing support systems for the implementation of the program [22]. In the context of this study, the elements related to the support system included the content of the program, the teaching staff and the related infrastructure. The evaluation process in the CIPP model addresses information about how well the program's implementation is going [23]. In the context of this study, teaching and learning activities are associated with the process component.

The learning level

This level measures changes in learning, as a result of training [13]. The changes can be characterized as changes in the cognitive domain (knowledge), the psychomotor domain (skills) and the affective domain (attitude) [15]. This study examined both the basic and technological knowledge and skills required in the job area, and the softs skills required in the job area.

\section{Method}

\subsection{Participants and Context}

The samples for this study were a cohort of 71 former INSEP students. This study was conducted a year after the students completed the INSEP program. The total participants included 61 males, who were $85.9 \%$ of the total participants, and 10 females. The participants were aged 21 to 26 years. Also, all the participants were Malay. More than half of the participants, specifically $64.8 \%$, held a diploma. The remaining $35.2 \%$ held first degree qualifications. $84.5 \%$ of the students specialized in engineering, while $9.9 \%$ specialized in management, and $5.6 \%$ specialized in science. 58 participants, or $81.7 \%$ of the total, were employed. The remaining $18.3 \%$ were still unemployed. Of the 58 participants who were employed, $52.1 \%$ were working in the area related to the INSEP course.

\subsection{Data Sources}

There are many different types of evaluation techniques, which are used depending on the purpose of the evaluation. As mentioned earlier, this study has focused on the first and second levels of the Kirkpatrick evaluation model. Level 1 (reaction) is related to learner satisfaction with the program, specifically what the learners' liked or felt about the program. Key evaluation techniques include asking, listening, or using questionnaires at the conclusion of a course [15]. Level 2 (learning) measures the extent to which learners experience change in knowledge, skills and attitude. Common tools of measurement at this level may include interviews, surveys, and tests, including pre and post-tests, for the control group. The latter allows for a better comparison of changes observed in the experimental group, against the changes observed in the control group. In this study, both reaction level and learning level were measured using a set of questionnaires. Therefore the measure of student's satisfaction was based on the students' perception only.

The questionnaire was divided into three sections:

- Section one: This section focused on demographics, gathering data about age, gender, ethnicity, specialization areas, and higher academic qualifications.

- Section two: In this section participants were asked to complete a questionnaire that consisted of 44 statements that addressed their views regarding: (a) the program inputs, including 6 items related to content, 3 items related to teaching staff, and 7 items related to provided infrastructure; (b) Implementation, including 10 items related to teaching and learning approaches, and industrial training; and (c) 15 items related to the output of the program. The statements were presented in a five-point scale of agreement ranging from ' 5 ' (strongly agree), to '1' (strongly disagree).

- Section three: Three open-ended questions related to suggestions for improving the program.

\section{Results}

Descriptive statistics were employed, in order to determine participant satisfaction regarding the program. The mean values were categorized into three levels of satisfaction, namely not satisfied (mean below 2.33), less satisfied (mean above 2.33 and below 3.66), and satisfied (mean above 3.66).

\subsection{Reaction Level}

Reaction to the Inputs of the Program

Table 1 shows the three elements included as the inputs of 
the program, namely the content of the program, teaching staff and infrastructure.

Table 1. Reaction to the input of the program.

\begin{tabular}{ll|l}
\hline Element 1: Content of the program & Mean & $\begin{array}{l}\text { Satisfaction } \\
\text { Level }\end{array}$ \\
\hline Emphasize useful hard skills in the job area & 4.17 & \\
Emphasize useful knowledge in the job area & 4.11 & \\
Theory and practical linkage & 4.07 & Satisfied \\
The syllabuses represent the job area & 4.04 & \\
Emphasize soft skills required in the job area & 3.71 & \\
\hline Exposure to new technology in the job area & 3.44 & Less \\
Mean & 3.92 & satisfied \\
Element 2: Teaching staffs & & \\
Knowledgeable in the job area & 4.22 & \\
Skilled in the job area & 4.01 & Satisfied \\
Showed good working ethics & 3.93 & \\
Rich of industrial experiences & 2.89 & Less \\
\hline Mean & 3.78 & satisfied \\
Element 3: Infrastructures & Satisfied \\
Sufficient learning materials & 3.93 & Satisfied \\
Safe learning environment & 3.68 & \\
Comfortable learning space & 3.24 & Less \\
Enough learning space & 3.14 & Less \\
Equipped with needed hand tools & 3.11 & satisfied \\
Equipped with new technology & 2.99 & \\
Equipped with needed machines & 2.93 & \\
Mean & 3.29 & satisfied \\
\hline
\end{tabular}

(a) Program content:

The students were satisfied with the emphasis placed on hard skills (4.17), knowledge of the job area (4.11), theory and practical linkage (4.07), and the representation of the training syllabuses related to the job area (4.04). However, the students were less satisfied in terms of exposure to the new technology (3.44). Overall, the students were satisfied with the content of the program, with a mean value of 3.92 .

(b) Teaching staff:

The students were satisfied with three out of four aspects related to the quality of teaching staff. The highest mean (4.22) applied to the knowledge aspect, followed by skills and the role model of good working ethics. However, they felt that the teaching staff lacked industrial experiences, as indicated by the mean value of 2.89 .

(c) Infrastructure:

The students were less satisfied with the infrastructure provided in the program. The students were satisfied with only two out of seven infrastructure aspects. They felt the program provided sufficient learning materials, and a safe learning environment, with mean values of 3.93 and 3.68 respectively. However, they were less satisfied with the elements related to the learning space (3.24 and 3.04), as well as the provided equipment, including hand tools (3.11), new technology (2.99) and machines (2.93).

Reaction to the Implementation of the Program

Table 2 presents the results of two elements of implementation, namely campus-based teaching and learning, and industrial training. (a) Teaching and learning:

The students were satisfied with 7 out of the 11 elements related to teaching and learning. The highest mean value (4.17) indicated that the students were satisfied with the effectiveness of the use of teaching and learning time. The lowest mean value (2.89) showed that the students were less satisfied with the encouragement of learning motivation. The overall mean value of 3.70 indicated that students were satisfied with the program's teaching and learning activities.

(b) Industrial training:

Industrial training is one of the important parts of the program. The students were satisfied with the suitability of the industry training, as indicated by the mean value of 3.90 . However, they felt less satisfied with the duration of the industrial training (2.77), and the placement process (2.56).

Table 2. Reaction to the Teaching and learning.

\begin{tabular}{|c|c|c|}
\hline Element 1: Teaching and learning & Mean & $\begin{array}{l}\text { Satisfaction } \\
\text { level }\end{array}$ \\
\hline Effective use of teaching and learning time & 4.17 & \multirow{4}{*}{ satisfied } \\
\hline Appropriate tasks/assignments & 4.00 & \\
\hline $\begin{array}{l}\text { Effective management of teaching and } \\
\text { learning activities }\end{array}$ & 4.11 & \\
\hline Promote self-directed learning & 3.99 & \\
\hline $\begin{array}{l}\text { Sufficient time for teaching and learning } \\
\text { activities }\end{array}$ & 3.95 & \\
\hline Effective practical class & 3.52 & \\
\hline Sufficient teaching aids & 3.47 & \multirow{4}{*}{ Less satisfied } \\
\hline Sufficient learning material & 3.45 & \\
\hline Effective theoretical class & 3.43 & \\
\hline Promote learning motivation & 2.89 & \\
\hline Mean & 3.70 & Less satisfied \\
\hline Element 2: Industrial training & & \\
\hline Industries related to the job area & 4.11 & Satisfied \\
\hline Duration of industrial training & 2.77 & \multirow{2}{*}{ Less satisfied } \\
\hline Placement process & 2.56 & \\
\hline Mean & 3.14 & Less satisfied \\
\hline
\end{tabular}

\subsection{Learning Impacts}

Table 3 shows that the learning components were categorized into two elements. The first element related to soft skills, while the second element related to knowledge and skills in the job area. The students were satisfied with six out of the eight soft skills. The highest impact recorded was in the development of interpersonal skills, with a mean value of 4.32. On the other hand, the impact on the leadership skill was limited, as indicated by the lowest mean value of 3.12 . Overall, a mean value of 3.85 indicated that the students were satisfied with the impact of the program on their soft skills. The second category measured learning related to knowledge and skills in the job area. The highest satisfaction was recorded in both basic hands-on skills and basic theoretical knowledge, with mean values of 4.20 and 4.14 respectively. However, the lowest mean value of 3.26 indicated that the program had a limited learning impact in regards to the acquisition of technological skills in the job area. Overall, the students were satisfied with the program's learning impact on knowledge and skills in the job area, with a mean value of 3.70 . 
Table 3. Learning impacts of the program.

\begin{tabular}{lll}
\hline Items & Mean & Level \\
\hline Element 1: Soft Skills & & \\
Interpersonal skill & 4.32 & \\
Confidence/self esteem & 4.22 & \\
Team-working skill & 4.14 & High \\
Problem solving skill & 4.06 & learning \\
Creative and critical thinking & 3.93 & impact \\
Professional ethics & 3.85 & \\
English proficiency & 3.69 & \\
Entrepreneurship & 3.37 & Less \\
& & learning \\
Leadership skill & 3.12 & impact \\
Mean & 3.85 & \\
Element 2: Skills and knowledge in the job area & & \\
Basic hand-on skills & 4.20 & High \\
Basic theoretical knowledge & 4.14 & learning \\
Technological knowledge in the area & 3.82 & impact \\
Advanced theoretical knowledge in the area & 3.41 & Less \\
Advance hand-on skills & 3.34 & learning \\
Technological skills in the area & 3.26 & impact \\
Mean & 3.70 & \\
\hline
\end{tabular}

\subsection{Overall Results}

Table 4 shows the three components measured in this study. The students were satisfied with two of the aspects.

Table 4. The overall results.

\begin{tabular}{|c|c|c|c|c|}
\hline Aspects & Elements & Mean & $\begin{array}{l}\text { Overall } \\
\text { mean }\end{array}$ & Level \\
\hline \multirow[t]{2}{*}{ Implementation } & $\begin{array}{l}\text { Teaching and } \\
\text { learning }\end{array}$ & 3.70 & \multirow[t]{2}{*}{3.42} & \multirow{2}{*}{$\begin{array}{l}\text { Less } \\
\text { satisfied }\end{array}$} \\
\hline & Industrial training & 3.14 & & \\
\hline \multirow{3}{*}{$\begin{array}{l}\text { Inputs of the } \\
\text { programme }\end{array}$} & The content & 3.92 & \multirow{3}{*}{3.68} & \multirow{4}{*}{ Satisfied } \\
\hline & Teaching staffs & 3.78 & & \\
\hline & Infrastructures & 3.29 & & \\
\hline \multirow{3}{*}{ Learning impacts } & Soft skills & 3.87 & \multirow[b]{2}{*}{3.85} & \\
\hline & $\begin{array}{l}\text { Skills and } \\
\text { knowledge in the } \\
\text { job area }\end{array}$ & 3.70 & & Satisfied \\
\hline & Mean & & 3.67 & Satisfied \\
\hline
\end{tabular}

The first component with the highest overall mean value of 3.85 was the learning impact of the program. This was followed by the input of the program with an overall mean value of 3.68. This indicated that the students were satisfied with the learning impacts, as well as the inputs of the program. However, the mean value was below 4.00. The results gave an indication that the satisfaction level was not really impressive. This can be connected to low satisfaction in regards to the program's implementation. The overall mean value was only 3.42 .

\subsection{Suggestion}

Open-ended questions required students to express their suggestions for the purpose of improving the program. Their suggestions could be divided into the following aspects:

- Industrial training: Extend the duration of the program, especially in regards to practical training. The students expressed disagreement with their placement in only one industry. They felt that in order to obtain more exposure, they should have been given the opportunity to go to more than one industry by reducing the duration in each industry to one month only. They also suggested that the overall duration of the program should be increased from seven months to one year.

- They also suggested that students should be assisted in getting a job after completing the program

\section{Discussion}

INSEP is a form of enrichment program for unemployed graduates. The main goal of the program is to equip graduates with appropriate competencies, relevant to the needs of the workplace. The results showed that $81.7 \%$ or 52 of the graduates were employed after participating in INSEP. However, the remaining $18.3 \%$ remained unemployed. Of the 58 participants who were employed, $52.1 \%$ were working in the area that related to the course undertaken during INSEP, and the remaining students worked in other areas. This result indicated that even a year after completing the INSEP program, unemployment still occurred. This study showed that the students were satisfied with the learning impacts of INSEP. However, the mean values were below the 4.00 point, which indicated that satisfaction with the learning Impacts was not really impressive, especially in regards to the impacts on technological knowledge and skills. This may due to the dissatisfaction of the implementation aspect. This can be connected to the industrial element, where there is dissatisfied with the duration of the industrial training. Industrial training refers to work experience undertaken during the program of study, as relevant to professional development prior to the completion of the training and education program. Through open-ended responses, the students indicated that they felt that the three month duration of the industrial training was too short. This finding was similar to a study of the effectiveness of an industrial internship in Sri Lanka. The study found that the students suggested that the durations of industrial training should be increased from six to 12 months [23]. Furthermore, the students in this study suggested that the placement should involve more than one industry. This raises the need to look back into the implementation of industrial training in INSEP.

In regards to the input of the program, satisfaction was not really impressive as shown by mean values that fell below 4.00. Of the three elements measured, the students were most satisfied with the content of the program compared to the quality of teaching staff, as well as the provided infrastructures. The students were satisfied with the teaching staff's expertise in terms of knowledge and skills. However, they felt that the teaching staff lacked industrial experiences. Industrial experience enables trainers or instructors to deliver and assess vocational training relevant to current industry practices [24]. Given the importance of teaching staff's industrial experiences, graduate enrichment programs like INSEP should give consideration to this issue.

The students were also less satisfied with the provided infrastructure. Infrastructure includes the basic needs of any training program. These include tools, machines, learning 
materials and learning space [23]. All these facilities are important for the implementation of the practical component of the training. This maybe one of the reasons why the students were less satisfied with the item 'effective practical classes' (with a mean value of 3.52). Furthermore, one of the main goals of INSEP is to give exposure in regards to the current technology of the job area. However, the findings of this study indicated that the students were less satisfied with the program level of being 'equipped with new technology' in the job area. The absence of this element contributed to limited exposure in regards to latest technology in the job area. This definitely does not contribute to finding a solution to the problem of unemployed graduates, who lack 'ready to work' skills such as technological knowledge and skills [5]. On the other hand, students were satisfied with the learning impact on soft skills. This indicates that INSEP is achieving its goal of improving soft skills among unemployed graduates. However, this is not sufficient enough for the graduates to survive in current employment, which requires up to date technological knowledge and skills.

\section{Conclusion}

This study indicates that some aspects of the INSEP program need further inspection, such as the infrastructure that relates to current technological knowledge and skills. There is a need for the related government agencies to provide a comprehensive requirement for the institutions offering the INSEP program. Continued supervision also needs to be undertaken in order to make sure the institution meets minimum requirements. Otherwise, the cost spent on the INSEP program will not help solve the problem of unemployed graduates.

\section{References}

[1] Kementerian Pengajian Tinggi Malaysia. Laporan Kajian Pengesanan Graduan, 2008.

[2] Berita Harian, Lahir Pekerja Mahir Tangani Pengangguran, muka surat, 5 Februari, 2006.

[3] Dokumen Rasmi Kementerian Kewangan, Tidak diterbitkan, 2006.

[4] F. Berlingieri and \& D. Erdsiek, D. How Relevant is Job Mismatch for German Graduates, http://ftp.zew.de/pub/zew-docs/dp/dp12075.pdf, 25 January, 2014.

[5] O. Zarina, M. Faridah, M. Nor Hasni, Y. Azizah,A.L. Rozmel, H. Harieza, M. Abdul Wahab \& K. Saran, Undergraduate Awareness and Readiness Towards Employability: The Significance of English: British Journal of Arts and Social Sciences, 2(2),2011, 122

[6] V. Wickramasinghe and L. Perea, L. Graduates, University Lecturers and Employers Perceptions Towards Employability Skills. Journal of Education and Training, 52(3), 2010, 226-244.
[7] Report of the National Committee of Inquiry into Higher Education, Higher Education in the Learning Societies (the Dearing Report, July 1997.

[8] Partnership for 21st Century Skills, 21st Century Skills Education \& Competitiveness, A resource and Policy Guide., Https:// 2008

[9] S. L. Wei, Unemployment among Graduates: Study of Employers' Perception on Graduates. Proceeding of International Conference on Social Science, Economics and Art 2011, Malaysia.

[10] Ministry of Higher Education, Malaysia. (2012). The National Graduate Employability Blueprint 2012 - 2017. Universiti Putra Malaysia Press, 2012.

[11] A. Mohamad, M. Masita and K. Noraini, Retraining Unemployed Graduates Through Entrepreneurship Program. Persidangan Kebangsaan Pendidikan Kejuruteraan dan Keusahawanan 25-26 September, 2010.

[12] C. McNamara, The Field Guide to Non-profit Program Design, Marketing, and Evaluation. Minneapolis: Authenticity Consulting, Retrieved February, 2012, from Http://www.mapap.org/library/evaluatn/fnl_eval.htm.

[13] D.L. Kirkpatrick, Evaluating Training Programs: the Four Levels. San Francisco, Brett-Koehler, 1998.

[14] D.L Stufflebeam, A Depth Study of the Evaluation Requirement, Theory into Practice, (6), 126-133.

[15] W.E. Brewer, Evaluation Models for Evaluating Educational Programs, in V.C. Wang, Assessing and Evaluating Adult Learning in Career and Technical Education. Zhe Jiang University Press, 2009.

[16] K. Arthur, R. Gage-Little and D. Munson. Training Kirkpatrick's Four Levels of Evaluation, Retrieved April 22, 2009, from http://www.dalemunson.com/products/Kirkpatrick\%20Present ation.pps.

[17] F. Levy and R.J. Mumane, New Division of Labour, How Computers are Creating the Next Job market, Http://www.massbenchmarks.org/publication/vol7il/.pdf.

[18] Occupational Safety and Health Administration (OSHA), Best Practices for Development, Delivery, and Evaluation of Susan Harwood Training Grants, Https://www.osha.gov/dte/sharwood/best-parctice.html.

[19] OECD, Building a High-Quality Teaching Profession Lessons from Around the World, Https://www2.ed.gov/.../background, 19, December, 2011.

[20] Costa, Teaching for, of, and about Thinking. In A. Costa (Ed), Developing Minds: A Resource Book for Teaching Thinking (pp.354-358), Victoria, Australia: Hawker Brownlow Education, 2001.

[21] R.A. Beghetto, Does Creativity Have a Place in Classroom Discussions? Prospective Teachers' Response Preferences, Thinking Skills and Creativity 2(1), 2007, 1-9.

[22] J.L. Fitzpatrick, J.R. Sanders and B.R. Worthen, Program Evaluation: Alternative Approaches and Practical Guidelines (3rd edn.), Boston: Pearson, 2004. 
[23] K. Kingsley and P. Niroshani, Students' Perception on the Effectiveness of Industrial Internship Programme, Proceedings of the International Conference on Global Business, Economics, Finance and Social Sciences, Thailand , 20-22 February 2015.

[24] M. Toze and and S.Tierney (2009), Keeping it Real, Industry Currency of Trainers in Queenslandhttp://www.vetpd.qld.gov.au/resources/pdf/ic/keep ing-it-real (February, 2013).

[25] M. Binks, Enterprise in Higher Education and the Graduate Labour Market: Education and Training, Vol. 38 No. 2, 1996, pp. 26-9.
[26] D. Johnson, The use of learning theories in the design of a work-based learning course at masters level: Innovations in Education and Training International, Vol. 37 No. 2, 2000, pp. 129-33.

[27] S. Okay and I. Sahin, A Study on the Opinions of the Students Attending the Faculty of Technical Education Regarding Industrial internship: International Journal of the Physical Sciences, Vol. 5 No. 7, 2010, pp. 1132-46. 